\title{
Effect of Service Quality, Product Quality, and Price on Consumer Satisfaction and Its Impact on Customer Loyalty at Bekasi Branch Superindo Supermarket
}

\author{
Imelda Aprileny* \\ Departement of Management \\ Sekolah Tinggi Ilmu Ekonomi Indonesia \\ Jakarta, Indonesia \\ *imelda_aprileny@stei.ac.id
}

\author{
Nelli Novyarni \\ Departement of Accounting \\ Sekolah Tinggi Ilmu Ekonomi Indonesia \\ Jakarta, Indonesia \\ nelli_novyarni@stei.ac.id
}

\begin{abstract}
The purpose of this study was to determine the effect of service quality, product quality and price on customer satisfaction and its impact on customer loyalty. The research is now conducted at the SuperIndo Supermarket Bekasi Branch. The strategy used in this study is to use an associative / correlational strategy. Correlational / associative research is research conducted to find the relationship or influence of one or more independent variables with one or more dependent variables. The research method used in this study is a survey method that uses questionnaire data collected from questions with a total sample of 96 people. While the sampling method in this study is purposive aside. Based on the results of research quality service (X1) and product quality (X2) does not affect consumer satisfaction Superindo supermarkets, prices (X3) affect consumer satisfaction (Y) Superindo Supermarket, service quality (X1) affect customer loyalty (Y2) Supermarket Superindo, product quality (X2) affect customer loyalty (Z) Superindo supermarkets, prices affect customer loyalty (Z) Superindo supermarkets, customer satisfaction (Y) affect customer loyalty (Z) Superindo supermarkets, service quality (X1), product quality (X2) and price (X3) affect consumer satisfaction (Y) supermarket Superindo North Bekasi branch. The magnitude of influence is $\mathbf{2 2 . 4 \%}$ and the remaining $\mathbf{7 7 . 6 \%}$ is influenced by other factors outside this study. Service quality (X1), product quality (X2), price (X3) and customer satisfaction (Y) as moderating variables affect Superindo supermarket customer loyalty. The amount of influence is $23.8 \%$ and the remaining $76.2 \%$ is influenced by other factors.
\end{abstract}

Keywords: service quality, product quality, price, customer satisfaction, customer loyalty

\section{INTRODUCTION}

The number of supermarket retailers in the city of Jakarta has provided special pleasure for these consumers and the community. They have many choices to shop at the supermarket in accordance with their wishes and desires. Likewise, very tight competition occurs in the retail industry. Retail business is a business activity that involves selling goods and services directly to end consumers. In its development, now the retail business in Indonesia is starting to transform from traditional retail business to modern retail business. Because now people want a comfortable place to shop. The development of modern retail business in Indonesia has increasingly mushroomed in almost all regions of Indonesia. It can be seen the emergence of several retail businesses that open branches in various regions in Indonesia such as Carrefour, SuperIndo, Giant, Lotte Mart, Alfamart, Indomaret and so on. So that this business opportunity is quite attractive to retailers and encourages retailers in Indonesia to always improve the quality of their business.

Likewise, retail companies in Indonesia Supermarkets Superindo which sell retail grocery products and fresh products consisting of vegetables, fruits, fish, and meat that serve the needs of consumers every day at an affordable price and their motto is fresher, more Save, Get Closer, with the quality of the services provided which is a symbol of the marketing strategy of the Superindo retail company which is an international business network spread all over the world, based in the Delhaize Group of Belgium.

\section{A. Formulation of The Problem}

Based on the background that has been described, the formulation of the problem in this study is "How does the influence of Service Quality, Product Quality and Price on Consumer Satisfaction and its impact on Customer Loyalty at SuperIndo, North Bekasi branch?"

\section{B. Specification of the Main Problem}

Referring to the background of the problem that remains elaborated the following research problems can be formulated:

- Is there an influence of service quality on customer satisfaction at the Superindo supermarket in Bekasi branch?

- Is there an influence on product quality on consumer satisfaction at the Superindo supermarket in Bekasi branch?

- Is there a price effect on consumer satisfaction at the Superindo supermarket in Bekasi branch?

- Is there an influence of service quality on customer loyalty in the Superindo supermarket in Bekasi branch? 
the period for data collection to be carried out is planned in March - April 2018.

\section{B. Research Strategies and Methods}

The strategy used in this research is to use an associative / correlational strategy. Correlational / associative research is research conducted to find the relationship or influence of one or more independent variables with one or more dependent variables [1].

\section{Research Methods}

The research method used in this study is a survey method namely data collection and analysis techniques in the form of opinions of the subjects studied by directly (interview) or indirectly (questionnaire), as a means of data collection in order to achieve the desired objectives namely knowing the effect between service quality and price towards customer satisfaction and customer loyalty.

\section{Population and Research Samples}

Population is a generalization area that consists of: objects / subjects that have certain qualities and characteristics determined by researchers to be studied and then drawn conclusions, According to Sugiono [2]. The target population in this study is all consumers who come to the Superindo supermarket in Bekasi branch.

According to Sugiono [2], the sample is part of the number and characteristics possessed by the population 48 . The sampling technique used in this study is Non-probability sampling. According to Sugiono [3], "Non-Probability Sampling is a sampling technique that does not provide the same opportunity / opportunity for each element or member of the population to be selected as a sample." Sampling is done by purposive sampling technique, with total 96 sample, sampling technique taken based on certain criteria or considerations, which is a minimum of 2 times in shopping.

Data analysis tool:

- Testing the coefficient of determination

- Path of analysis

- Hypothesis test

- SPSS (Statistical Program For Social Sciences) V.22

\section{RESULTS AND DISCUSSION}

Calculation results (outputs) and path model diagrams sub-s structure 1 , as follows:

Subtitles structure:

$$
\mathrm{Y}=0.120 \mathrm{X} 1+0.152 \mathrm{X} 2+0.380 \mathrm{X} 3+0.776 \mathrm{e}_{1}
$$

\section{A. Research Location and Time}

All research data collection activities will be carried out at Superindo. Bekasi Branch. The time of this research is planned to be around 4 (four) months, from March to June 2018. While 
TABLE I. S S S $\quad$ SU-STRUCTURE SUMMARY MODEL 1

\begin{tabular}{|c|c|c|l|c|}
\hline \multicolumn{5}{|c|}{ Model Summary } \\
\hline Model & $\mathbf{R}$ & $\begin{array}{c}\text { R } \\
\text { Square }\end{array}$ & $\begin{array}{l}\text { Adjusted } \\
\text { R Square }\end{array}$ & $\begin{array}{c}\text { Std. Error of the } \\
\text { Estimate }\end{array}$ \\
\hline 1 & $.473 \mathrm{a}$ & .224 & .198 & .66083 \\
\hline
\end{tabular}

The magnitude of the number $\mathrm{R} 2=0.224$. This figure is used to determine the effect of service quality, product quality and price on customer satisfaction. This figure means that the effect of service quality, product quality and price on simultaneous customer satisfaction is $22.4 \%$. While the remaining $77.6 \%$ or 0.776 is influenced by other factors outside the study. The results of the calculation (output) and substructure path diagram model 2 , as follows:

Sub-structure equation 2:

$$
\mathrm{Z}=-0.235 \mathrm{X} 1-0,112 \mathrm{X} 2-0,103 \mathrm{X} 3+0,755 \mathrm{Y}+0,762 \mathrm{e} 2
$$

TABLE II. SUB-STRUCTURE SUMMARY MODEL 2

\begin{tabular}{|c|c|c|c|c|}
\hline \multicolumn{5}{|c|}{ Model Summary } \\
\hline Model & $\mathbf{R}$ & $\begin{array}{c}\text { R } \\
\text { Square }\end{array}$ & $\begin{array}{c}\text { Adjusted R } \\
\text { Square }\end{array}$ & $\begin{array}{c}\text { Std. Error of the } \\
\text { Estimate }\end{array}$ \\
\hline 1 & $.488^{\mathrm{a}}$ & .238 & .204 & 2.13792 \\
\hline \multicolumn{5}{|c|}{ a. Predictors: (Constant), Moderating, service_Quality, Product Quality, Price }
\end{tabular}

The magnitude of the number $\mathrm{R} 2=0.238$. This figure is used to determine the effect of service quality, product quality and price on customer loyalty with customer satisfaction as a moderating variable. This figure means that the effect of service quality, product quality, and price on customer loyalty through simultaneous customer satisfaction is $23.8 \%$. While the remaining $76.2 \%$ or 0.762 are influenced by other factors outside the study.

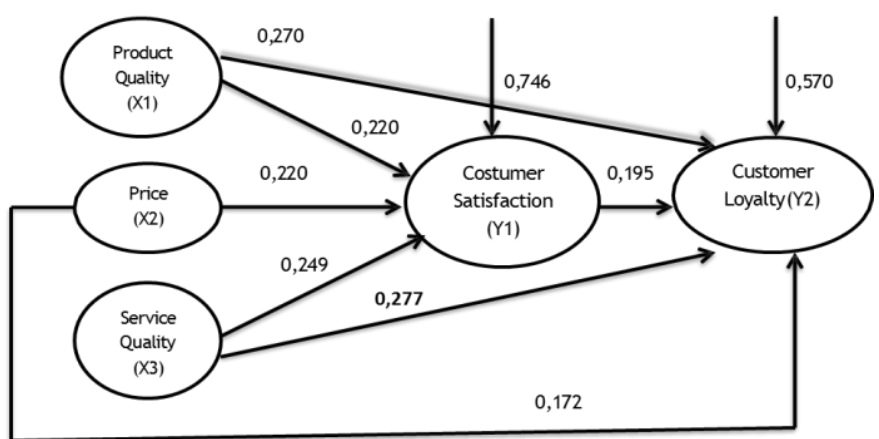

Fig. 1. Diagram of the results of structural equations 1 and 2 .

\section{A. Calculation of Influence}

1) Direct effect (direct effect):

- The effect of service quality variables on customer satisfaction by 0.120 .

- The effect of product quality variables on customer satisfaction by 0.152 .

- The effect of price variables on customer satisfaction by 0.380 .
- The effect of service quality variables on customer loyalty of 0.235 .

- The effect of product quality variables on customer loyalty of 0.112 .

- The effect of price variables on customer loyalty of 0.103 .

- The effect of customer satisfaction variables on customer loyalty of 0,400 .

2) Indirect effect (indirect effect):

- The effect of service quality variables on customer loyalty through customer satisfaction is $(0,120 \times 0,400)$ $=0.048$.

- The effect of product quality variables on customer loyalty through customer satisfaction is $(0.152 \times 0.400)$ $=0.0608$.

- The effect of price variables on customer loyalty through customer satisfaction is $(0.380 \times 0.400)=$ 0.152 .

3) Total effect (total effect):

- The effect of service quality variables on customer loyalty through customer satisfaction is $(0.235+0.048)$ $=0.283$.

- The effect of product quality variables on customer loyalty through customer satisfaction is $(0.112+$ $0.0608)=0.1728$.

- The effect of price variables on customer loyalty through customer satisfaction is $(0.103+0.152)=$ 0.255 .

\section{B. Research Result}

Judging from the results of testing the hypothesis partially and simultaneously shows that:

- The effect of service quality (X1) on consumer satisfaction (Y) Superindo Supermarket in Bekasi branch is negative and not significant. Partial testing is shown from the sub-structural coefficients 1 table obtained beta values of -0.012 and negative with a significance value of 0.931 , because the significance value $>0.05$ then the decision is Ha rejected and Ho is accepted, which means the coefficient of analysis of service quality path has no effect positively and significantly to consumer satisfaction.

- The effect of product quality (X2) on consumer satisfaction (Y) Superindo Supermarket Bekasi branch is positive and not significant. Partial testing is shown from the sub-structural coefficients 1 table obtained beta values of 0.152 and positive with a significance value of 0.206 , because the significance value $>0.05$ then the decision is $\mathrm{Ha}$ rejected and Ho is accepted, which means the coefficient of analysis of the product quality path has a positive effect and not significant to customer satisfaction. 
variables on customer loyalty (Z) Superindo supermarkets simultaneously is positive and significant. Tests shown from the Anova sub-structure 2 table obtained value $(\mathrm{sig})=0,000$ because the significance value $<0.05$ then the decision is Ho is rejected and $\mathrm{Ha}$ is accepted, which means the coefficient of path analysis of service quality, product quality, price and customer satisfaction as a moderating variable positive and significant effect on customer loyalty. Thus it can be obtained information that service quality, product quality, price, and customer satisfaction simultaneously and significantly influence and the amount of contribution that directly affects customer loyalty Superindo supermarkets is $23.8 \%$ and the remaining $76.2 \%$ is influenced by other factors outside this research.

\section{CONCLUSION AND SUGGESTION} a positive effect and significant to customer loyalty.

- The effect of product quality (X2) on customer loyalty (Z) of SuperIndo's supermarkets is positive and significant. Partial testing is shown from the substructural coefficients 2 table obtained beta values of 0.172 and positive with a signification customer loyalty.

- The effect of price (X3) on customer loyalty (Z) of Superindo supermarkets is positive and significant. Partial testing is shown from the sub-structural coefficients table 2 obtained a beta value of 0.277 and positive with a significance value of 0.003 , because the significance value $<0.05$ then the decision is Ho is rejected and $\mathrm{Ha}$ is accepted, which means the price path analysis coefficient has a positive effect and significant to customer loyalty.

- The effect of customer satisfaction (Y) on customer loyalty $(\mathrm{Z})$ of Superindo supermarkets is positive and significant. Partial testing is shown from the substructural coefficients 2 table obtained beta values of 0.755 and positive with a significance value of 0.001 , because the significance value $<0.05$ then the decision is Ho is rejected and $\mathrm{Ha}$ is accepted, which means the coefficient of analysis of the path of consumer satisfaction has a positive effect and significant to customer loyalty.

- The effect of service quality (X1), product quality (X2) and price (X3) on consumer satisfaction (Y) at Superindo supermarket, Bekasi branch simultaneously is positive and significant. Tests shown from the Anova sub-structure 1 table obtained value $(\mathrm{sig})=0,000$ because the significance value $<0.05$ then the decision is Ho is rejected and $\mathrm{Ha}$ is accepted, which means the coefficient of path analysis of service quality, product quality and price has a positive and significant effect on consumer satisfaction. Quality of service (X1), product quality (X2) and price (X3) simultaneously have a significant effect on customer satisfaction $(\mathrm{Y})$ in the Superindo supermarket.

- The effect of service quality (X1), product quality (X2), price (X3) and customer satisfaction (Y) as moderating

\section{A. Conclusion}

Based on the results of the study it can be concluded as follows:

- Service quality does not affect consumer satisfaction (Y) Superindo Supermarket, Bekasi branch.

- Product quality does not affect consumer satisfaction (Y) Superindo Supermarket, Bekasi branch.

- Price affects consumer satisfaction (Y) Superindo Supermarket, Bekasi branch.

- Quality of service (X1) affects customer loyalty (Y2) Supermarket SuperIndo.

- Product quality (X2) affects customer loyalty (Z) Superindo supermarket.

- Price affects customer loyalty (Z) for Superindo supermarkets.

- Consumer satisfaction (Y) affects customer loyalty (Z) supermarket Superindo.

- Service quality (X1), product quality (X2) and price (X3) affect consumer satisfaction (Y) Superindo supermarket, North Bekasi branch. The magnitude of influence is $22.4 \%$ and the remaining $77.6 \%$ is influenced by other factors outside this study.

- Service quality (X1), product quality (X2), price (X3) and customer satisfaction (Y) as moderating variables affect Superindo supermarket customer loyalty. The amount of influence is $23.8 \%$ and the remaining $76.2 \%$ is influenced by other factors outside this study.

\section{B. Suggestion}

Suggestions based on the results of the study are as follows:

- Service quality does not need to be a consideration for Superindo because Superindo sells basic needs and Superindo is a type of supermarket where customers 


\section{REFERENCES}

buy themselves.

- Product quality also does not need to be taken into consideration because the products of daily needs are not seen from the quality but the product must be available at the same time because it is a basic need that must be available every day even though quality is not consider.
[1] Suryani dan Hendryadi, Buku Metode Riset Kuantitatif, Jakarta: Prenadamedia Group, 2015.

[2] Sugiono, Metode Penelitian Pendidikan: Pendekatan Kuantitatif, Kualitatif, dan R\&D, Bandung: Alfabeta, 2015.

[3] Sugiyono, Management Research Methods, Bandung: Alfabeta, 2016. 